\title{
Konseling untuk keluarga untuk meningkatkan sikap belajar dan kedisiplinan pada anak Intelectual Disability
}

Nurul Hidayah, Universitas Muhammadiyah Malang, Malang, Indonesia

Korespondonesi:

Nurul Hidayah, Universitas Muhammadiyah Malang, Malang, email: yuyunsidar97@gmail.com

\section{Riwayat artikel Naskah diterima: 16/02/2018}

Revisi diterima: 20/06/2018

Naskah disetujui: $28 / 06 / 2018$

\begin{abstract}
Abstrak
AI anak perempuan berusia 12 tahun yang didiagnosa mengalami intelekutual disabilitas. Taraf kecerdasan klien termasuk dalam kategori Retardasi mental dengan kapasitas intelekual IQ 64 skala Wechsler, hal ini menunjukkan bahwa klien memerlukan bimbingan khusus untuk melakukan hal-hal yang dapat dilakukan oleh orang-orang seusianya. Klien mengalami problem dalam pengendalian emosi. Klien sering kali marah dan mengamuk jika keinginannya tidak terpenuhi atau ada hal yang tidak disukainya. Asesmen yang digunakan adalah wawancara, observasi,WISC. Tujuan intervesi yaitu untuk mengatasi problem emosi pada anak.

Kata kunci:Intelectual disability dan perilaku anak
\end{abstract}

\section{Latar Belakang}

Intelectual disability merupakan gangguan intelektual selama periode perkembangan dengan onset selama periode perkembangan yang mencakup defisit fungsi intelektual dan adaptif dalam domain konseptual, sosial, dan praktis (APA,2013). Disabilitas intelektual merupakan suatu kelainan yang multifaktorial, bisa faktor keturunan (disabilitas intelektual genetik) dan mungkin juga tidak diketahui (disabilitas intelektual simpleks).Keduanya dinamakan juga disabilitas intelektual primer.Disabilitas intelektual sekunder disebabkan faktor-faktor dari luar yang diketahui dan faktor-faktor ini mempengaruhi otak mungkin pada waktu pranatal, perinatal atau postnatal.Salah satu penyebab disabilitas intelektual adalah genetik. Kelainan kromosom sering menjadi penyebab keterbelakangan mental dan sering kali berkaitan dengan kelainan fisik lainnya(Ar-rasily \& Dewi, 2016).

Anak dengan intelektual disabilitas memiliki kesulitan dalam memahami isyarat sosial dengan teman sebaya secara akurat. Komunikasi, percakapan, dan bahasa mereka lebih konkrit atau tidak dewasa dari yang diharapkan untuk anak seusia mereka. Anak dengan intelektual 
disabilitas memiliki kesulitan untuk mengatur emosi dan perilaku dengan cara yang sesuai. Kesulitan ini akan diperhatikan oleh teman-teman sebayanya dalam pergaulan sosial. Anak dengan intelektual memiliki pemahaman yang terbatas tentang risiko dan situasi sosial dan mereka berisiko dimanipulasi oleh orang lain (APA,2013).

Intelectual disability ditandai dengan defisit dalam fungsi intelektual, seperti penalaran, pemecahan masalah, perencanaan, pemikiran abstrak, penilaian, pembelajaran akademis, dan belajar dari pengalaman, dikonfirmasi oleh penilaian klinis dan tes kecerdasan individual yang terstandardisasi (APA,2013). Klien pada kasus ini memiliki kemampuan yang kurang dalam bidang akademik dan hasil tes WISC menunjukkan skor 64 skala wechsler yang termasuk dalam kategori Retardasi Mental, klien memiliki permasalahan dalam mengendalikan emosinya sehingga jika terdapat hal yang tidak diinginkan atau tidak disukainya maka dia akan mengamuk dan marah kepada orang-orang disekitarnya.

Wali klien merasa bahwasanya klien sangat sulit diatur dan terbiasa berbuat seenaknya sendiri. Misalnya jika klien ditegur karena terlalu lama menonton televisi, maka klien akan marah dan melempar barang-barang di sekitarnya. Wali klien akhirnya membiarkan klien berbuat sesukanya daripada dia mengamuk dan marah. Kurangnya stimulus dan adanya pembiaran terhadap perilaku klien dari keluarga diduga menjadi penyebab terbentuknya masalah emosi yang dimiliki klien Pada kasus ini terapis menggunakan intervensi berupa konseling pada keluarga yang bertujuan untuk mengatasi problem emosi pada klien. Intervensi ini didasarkan bahwa untuk mengatasi problem emosi yang dimiliki klien dibutuhkan dukungan dan intervensi lanjutan dari keluarga. Golden dan Sherwood menjelaskan bahwa konseling keluarga adalah metode yang dirancang dan difokuskan pada keluarga dalam usaha untuk membantu memecahkan masalah perilaku klien, sehingga konseling keluarga merupakan proses bantuan yang diberikan kepada individu anggota keluarga dalam memecahkan masalah kelurga yang dihadapinya (Latipun, 2001).

Menurut Krumboltz (1965) semua konseling adalah konseling perilaku, meskipun kadang-kadang konselor tampaknya melupakan fakta ini. Krumboltz menggunakan istilah konseling behavioral hanya sebagai pengingat bahwa semua konseling dirancang untuk memengaruhi perilaku klien. Krumboltz menyatakan tidak ada konselor atau psikoterapis dari aliran pemikiran mana pun yang akan menyangkal bahwa ia berharap untuk mempengaruhi perilaku kliennya. Konselor perilaku tertarik tidak hanya dalam variabel yang mengendalikan perilaku, tetapi lebih tepat dalam menentukan bagaimana variabel dapat digunakan untuk mempromosikan perubahan perilaku yang diinginkan klien (Hasford, 2015)

Coreymenjelaskan bahwa proses konseling yang terbangun dalam pendekatan behavioristik terdiri dari empat hal yaitu ; (1) tujuan terapi diarahkan untuk memformulasikan tujuan secara spesifik, jelas, konkrit, dimengerti dan diterima oleh konseli, (2) peran dan fungsi konselor/terapis adalah mengembangkan keterampilan menyimpulkan, reflection, clarification, dan open-ended questioning, (3) kesadaran konseli dalam melakukan terapi dan partisipasi konselor ketika proses terapi berlangsung akan memberikan pengalaman positif pada konseli dalam terapi, dan (4) memberi kesempatan pada konseli karena kerjasama dan harapan positif dari konseli akan membuat hubungan terapis lebih efektif(Sanyata, 2012).

\section{Metode Asesmen}

Metode asessmen yang digunakan adalah (1) Wawancara klinis, yaitu wawancara yang dilakukan guna mengumpulkan informasi secara mendalam baik melalui klien maupun orang-orang disekitar subjek, (2) Weschler Intelligence Scale for Children (WISC) untuk mengetahui kapasitas intelektual guna memprediksi seberapa jauh pemahaman klien terhadap intervensi yang akan diberikan, dan (3) Tes Grafis untuk mengungkap kepribadian klien secara mendalam. Tes grafis yang diberikan adalah Draw a Person (DAP), BAUM, House Tree Person (HTP). 


\section{Presentasi Kasus}

Klien adalah seorang anak perempuan berusia 12 tahun yang duduk di bangku kelas 6 SD di salah satu sekolah inklusi di kota Malang. Klien merupakan anak tunggal yang telah yatim piatu dan kini tinggal bersama dengan keluarga tante klien. Ibu klien memiliki riwayat penyakit epilepsi dan ketika mengandung klien, ibunya beberapa kali sering jatuh sakit dan pingsan. Ketika klien berusia dua tahun, ayah klien yang saat itu berusia tiga puluh tahun meninggal dunia karena sakit, ibu klien memutuskan untuk membawa klien tinggal bersama dengan keluarga kakaknya. Ketika klien berusia lima tahun ibu klien meninggal dunia pada usia tiga puluh dua tahun dan kini hak asuh klien di bawah asuhan tantenya. Klien tinggal dengan tante, om dan sepupunya yang sudah dewasa. Tante klien sangat menyayangi klien dan sudah menganggapnya sebagai anak sendiri karena dari kecil sudah tinggal bersama.

Kemunduran yang dimiliki klien diketahui keluarganya ketika klien masuk ke sekolah dasar, klien tidak bisa mengikuti pelajaran seperti teman seusianya. Menurut tantenya selama bayi dan balita klien sehat dan kebutuhannya tercukupi. Perilaku klien di rumah seringkali mennyusahkan keluarga klien. Klien yang begitu pulang dari sekolah terbiasa masuk rumah tanpa mengetuk atau memberi salam. Klien membuang tasnya begitu saja dan langsung menonton televisi tanpa mengganti baju. Tante klien seringkali tidak tahu cara menghadapi klien karena perilakunya yang tidak bisa diatur. Menurut tantenya, klien seringkali sengaja melakukan hal-hal yang membuat orang lain kesal dengan melakukan apa yang tidak disenangi tantenya. Tante klien merasa tidak bisa mengatasi perilakunya yang demikian karena begitu ditegur dia akan marah dan mengamuk bahkan sampai melempar barang-barang di rumahnya. Tantenya khawatir jika dia akan tetap seperti itu sampai besar nanti dan perilakunya tidak berubah tidak ada yang bisa mengingatkannya.

Dari hasil asesmen yang dilakukan menunjukkan klien memenuhi kriteria diagnostik gangguan intelektual disabilitas. Intelektual disabilitas dapat ditegakkan dengan terbatasnya fungsi kognitif dan fungsi adaptif serta terjadi pada masa perkembangan pada anak sebalum usia 18 tahun (APA, 2013). Hasil tes WISC menyatakan klien memiliki IQ 64 dalam skala Wecshler yang termasuk dalam kategori retardasi mental.

Klien saat ini duduk di bangku kelas 5 SD sekolah inklusi dengan materi khusus yang diberikan padanya setara kelas 2 SD. Klien sudah dapat membaca dan menulis meskipun kini tanpa guru pendamping. Klien lebih banyak melamun dan diam ketika berada di kelas. Menurut teman sekelasnya, klien tidak banyak berbicara dan lebih memilih bergaul dengan anak-anak yang lebih muda darinya. Klien sering menolak dan tidak mau jika diajak bermain oleh teman sebayanya. Jika di rumah, klien juga terbiasa bermain dengan anak-anak yang lebih kecil darinya dan seringkali bermain sampai lupa waktu. Tante klien bingung menghadapi perilaku klien yang sering berbuat semaunya sendiri dan jika ditegur dia akan marah dan mengamuk. Tante klien yang bekerja sebagai penjahit di rumah dan memiliki banyak orderan tidak memiliki banyak waktu untuk klien, sehingga jika klien sudah tidak mau diingatkan atau mengamuk maka tantenya akan membiarkan saja. Sesungguhnya tante klien merasa kesal sekaligus kasihan dengan klien, kesal karena klien suka berperilaku seenaknya sendiri, tidak mau diatur, sering marah dan melempar barang-barang di rumah. Di sisi lain, tante klien merasa kasihan karena dengan perilakunya tersebut tantenya takut jika besar nanti dia akan dikucilkan dan tidak ada yang bisa berteman baik dengannya.

Dinamika permasalahan klien dapat dijabarkan dalam teori tingkah laku Skinner dalam operan conditioning yang menyatakan bahwa tingkah laku yang diberi penguatan cenderung untuk kembali diulang lagi (Corey, 2010). Klien yang kini diasuh oleh walinya yaitu tantenya yang sibuk, cenderung kurang mendapat stimulus bahkan sering mendapatkan pembiaran dari tingkah lakunya, sehingga hal ini membuat klien mengalami proses belajar yang salah karena tidak ada yang mengingatkannya secara terus menerus. Perilaku klien yang begitu pulang 
sekolah langsung masuk rumah tanpa memberikan salam, melempar tasnya dan langsung menonton televisi tanpa mengganti baju seringkali mendapatkan pembiaran dari tantenya. Tantenya yang bekerja sebagai seorang penjahit sudah cukup sibuk dengan pekerjaannya. Menurut tantenya dia sudah cukup mengingatkan namun pada dasarnya klien memang sulit diatur. Anggota keluarga lain yang tinggal bersama klien yaitu om (suami dari tante klien) dan kakak sepupunya baru akan pulang bekerja ketika menjelang maghrib. Tante klien mengaku tidak bisa mendampingi klien untuk belajar karena harus bekerja, jika diingatkan untuk mengerjakan PR atau belajar klien hanya diam tidak memberi respon bahkan tetap menonton televisi bahkan terkadang marah dan mengamuk sehingga anggota keluarga merasa malas dan kesal dengan perilaku klien.

Tingkah laku klien yang jika tidak suka sesuatu akan marah atau mengamuk dan melempar barang-barang disekitarnya mendapatkan respon pembiaran dari anggota keluarganya yang beranggapan jika klien akan berhenti sendiri marah atau mengamuk jika sudah puas. Pembiaran yang dilakukan oleh anggota keluarga klien membuat klien mendapatkan penguatan dari perilakunya yang berdampak pada membuatnya selalu mengulang-ulang perilaku tersebut. Klien belum diajari untuk mengendalikan emosinya sehingga ketika ada sesuatu yang tidak dia sukai dia akan marah, mengambek, mengamuk atau melempar barang-barang di sekitarnya.

\section{Diagnosis dan Prognosis}

\section{Diagnosis}

Berdasarkan hasil uraian kasus, hasil asesmen dan rujukan yang terdapat di DSM V, maka dapat didiagnosis bahwa klien telah memenuhi kriteria diagnostik Intelectual Disability. Intelectual Disability yang ditandai dengan kemampuan yang rendah dalam bidang akademik, komunikasi yang minim dengan orang-orang di sekitarnya dan lebih menunjukkan ketertarikan dengan anak-anak yang lebih muda darinya untuk bergaul dan bermain bersama.Klien berperilaku tidak seperti anak seusianya dan butuh pertolongan orang dewasa untuk tugas kesehariannya.

\section{Prognosis}

Terapis memperkirakan keberhasilan klien dalam melakukan terapi adalah baik karena adanya dukungan dari berbagai pihak yaitu keluarga, dan guru di sekolah.

\section{Intervensi}

Pada kasus ini, terapis memberikan kegiatan intervensi berupa konseling yang dilakukan kepada keluargayaitu tante klien yang bertujuanuntuk mengatasi problem emosi dan perilaku pada anak intelektual disabilitas. Pemberian intervensi ini didasari oleh permasalahan utama klien yang bersifat urgent saat ini yaitu kurangnya pengendalian emosi pada klien intelektual disabilitas. Intervensi yang digunakan dalam kasus ini adalah konseling kepada tante yang menjadi keluarga atau wali klien untuk mengatasi problem emosi dan perilaku pada klien. Target intervensi adalah untuk mengajarkan klien pengalihan emosi dan perilaku yang lebih adaptif melalui konseling kepada keluarga .

Terapis memberikan intervensi berupa konseling yang diberikan kepada keluarga yaitu tantedengan bertujuanuntuk mengatasi problem emosi pada klien. Konseling adalah suatu proses yang terjadi dalam hubungan seseorang dengan seseorang yaitu individu yang mengalami masalah yang tak dapat diatasinya, dengan seorang petugas profesional yang telah memperoleh latihan dan pengalaman untuk membantu agar klien memecahkan kesulitannya (Sofyan, 2007). Pemberian konseling individu bertujuan untuk mengurangi perilaku maladaptif sebagaimana penelitian Erlina yang menjelaskan bahwa konseling individu dapat mengurangi perilaku maladaptif menjadi lebih adaptif (Erlina \& Fitri, 2016). Konseling sebagai intervensi pada 
kasus ini untuk mengajarkan kepada keluraga untuk mengajarkan kepada anak dalam mengelola emosinya sehingga anak dapat belajar untuk mengendalikan emosi. Tante klien diajarkan untuk memberikan perhatian kepada klien, mengalihkan perhatian klien ketika sedang marah kepada hal lain yang disukainya, dan mengajak dan mengajarkan klien kepada aktivitas positif yang dapat meluapkan emosinya.

Sesi pertama: Identifikasi masalah klien. Sesi pertama terapis menanyakan keadaan klien kepada keluarga dan guru di rumah. dari hasil asesmen berdasarkan DSM V yang dilakukan, ditemukan bahwa klien mengalami gangguan Intelektual disabilitas dengan permasalahan problem emosi pada anak

Sesi kedua: Menetapkan tujuan. Pada sesi ini terapis menjelaskan kepada keluarga klien bahwa intervensi yang dilakukan bertujuan untuk mengajarkan kepada klien untuk mengendalikan emosinya. Terapis menjelaskan kepada keluarga bahwa intervensi ini melibatkan adanya dukungan dari pihak keluarga untuk melancarkan jalannya intervensi.

Sesi ketiga: Memberikan perhatian pada anak. Terapis menjelaskan kepada keluarga bahwa klien memiliki kebutuhan khusus lebih dari anak-anak lainnya. Mengajarkan sesuatu hal kepada klien pun tidak dapat dilakukan dengan satu kali ajaran saja melainkan harus diulang berkali-kali. Klien butuh perhatian khusus dan juga pengulangan berulang-ulang untuk mengajarkan sesuatu yang baru. Terapis dan keluarga sepakat untuk mengajarkan klien mengucapkan salam dan mengetuk pintu ketika masuk rumah. Tante klien diminta menunggu di depan pintu ketika klien pulang sekolah dan menyambut klien ketika datang. Klien diajari adab untuk masuk ke dalam rumah. Hal ini juga sebagai perhatian terhadap klien sehingga klien lebih merasa dipedulikan.

Sesi keempat: Pengalihan pada hal yang disukai anak. Terapis mengajarkan kepada keluarga bahwa ketika klien tidak dapat mengendalikan emosinya atau dia sedang marah atau mengamuk maka hal yang dapat dilakukan adalah mengalihkannya kepada hal yang lain yang dapat membuatnya lupa sehingga urung atau dapat meredam amarahnya. Pengalihan kepada hal yang disukai klien menjadi alternatif yang baik untuk segera melupakan amarah klien. Keluarga memilih untuk mengajak klien melakukan hal yang disukai klien yaitu menggambar dan menonton televisi yang sekiranya kegiatan tersebut dapat meredam amarah klien.

Sesi kelima: Aktivitas yang dapat mengeluarkan emosi. Terapis mengajarkan kepada keluarga bahwa hal lain yang dapat dilakukan untuk mengajarkan klien pengendalian emosi adalah dengan mengajak klien kepada aktivitas yang dapat mengeluarkan emosinya. Keluarga membawa klien ke taman bermain yang di sana klien dapat berlari-lari dan membawa klien pergi tempat renang sehingga klien bisa meluapkan emosinya.

Sesi Keenam: Evaluasi. Terapis dan keluarga mengevaluasi perkembangan yang dialami klien selama proses intervensi ini. Klien mulai terbiasa mengucapkan salam walau dan mau mengganti bajunya dengan bimbingan tantenya. Klien juga belajar meluapkan emosinya dengan kegiatan-kegiatan yang dilakukan bersama keluarga seperti ke tempat berenang untuk bermain bersama.

Sesi Ketujuh: Terminasi. Terapis memotivasi keluarga klien agar senatiasa mendampingi klien dalam melakukan aktivitas yang mengandung pengajaran tentang bagaimana klien mengelola emosinya seperti yang telah dilakukan dalam tahapan intervensi sehingga klien dapat belajar untuk mengendalikan emosi. Terapis meminta kepada wali klien agar dapat bergantian dengan anggota keluarga yang lain untuk menemani klien melakukan aktivitas-aktivitas positif sehingga klien merasakan perhatian dari anggota keluarga dan menjadi motivasi baginya. 


\section{Hasil dan Pembahasan}

\section{Hasil}

Intervensi berupa konseling keluarga yang telah dilakukan menunjukkan terdapat capaian yang dikehendaki oleh klien dan terapis yaitu untuk mengatasi problem emosi pada anak intelektual disabilitas. Konseling keluarga dengan pendekatan behavior dipilih sebagai intervensi pada kasus ini untuk mengajarkan anak dalam mengelola emosinya sehingga anak dapat belajar untuk mengendalikan emosi. Anggota keluarga diajarkan untuk memberikan perhatian kepada klien, mengalihkan perhatian klien ketika sedang marah kepada hal lain yang disukainya, dan mengajak dan mengajarkan klien kepada aktivitas positif yang dapat meluapkan emosinya.

Konseling yang dilakukan kepada keluarga pada kasus ini dilaksanakan dalam enam sesi. Setelah menetapkan tujuan yang dikehendaki bersama antara terapis dan keluarga yaitu untuk mengatasi problem emosi anak. Terapis kemudian menjelaskan kepada keluarga bahwa klien memiliki kebutuhan khusus lebih dari anak-anak lainnya. Mengajarkan sesuatu hal kepada klien pun tidak dapat dilakukan dengan satu kali ajaran saja melainkan harus diulang berkali-kali. Klien membutuhkan perhatian khusus dan pengulangan yang berulang-ulang untuk mempelajari sesuatu kebiasaan baru.

Hasil dari intervensi ini klien belajar untuk dapat mengucapkan salam dan mengetuk pintu ketika masuk rumah setelah sebelumnya hanya masuk dan membuang tasnya di depan pintu. Klien diajari bagaimana adab untuk masuk ke dalam rumah. Tante klien diminta untuk melakukan pengulangan beberapa hari untuk menyambut klien sepulang dari sekolah sehingga dapat menjadi kebiasaan klien sekaligus juga sebagai perhatian terhadap klien sehingga klien lebih merasa dipedulikan.

Hasil dari intervensi ini keluarga dan klien belajar jika klien sedang tidak dapat mengendalikan emosinya atau dia sedang marah atau mengamuk maka dapat dilakukan adalah mengalihkannya kepada hal yang lain yang dapat membuatnya lupa sehingga urung atau dapat meredam amarahnya. Pengalihan kepada hal yang disukai klien menjadi alternatif yang baik untuk segera melupakan amarah klien. Keluarga memilih untuk mengajak klien melakukan hal yang disukai klien yaitu menggambar dan menonton televisi yang sekiranya kegiatan tersebut dapat meredam amarah klien.

Terapis mengajarkan kepada keluarga bahwa hal lain yang dapat dilakukan untuk mengajarkan klien dalam mengendalikan emosi dan perilakunya adalah dengan mengajak klien kepada aktivitas yang dapat mengeluarkan emosinya. Keluarga membawa klien ke taman bermain yang di sana klien dapat berlari-lari dan membawa klien pergi tempat renang sehingga klien bisa meluapkan emosinya.

Hasil dari evaluasi menunjukkan terdapat perubahan sebelum dan sesudah intervensi dilakukan sebagaimana ditunjukkan pada Tabel 1. Intervensi yang dilakukan selama satu minggu dengan pendampingan keluarga menunjukkan perubahan perilaku klien yang dimulai dari klien yang belajar mengetuk pintu dan memberi salam. Tante klien mengajari klien untuk belajar mengetuk pintu dan memberi salam dan belajar untuk mengganti baju sepulang sekolah selama sepekan setelah klien pulang sekolah. Selama sepekan dalam masa intervensi klien pernah mengamuk sebanyak tiga kali yang kemudian dialihkan oleh tantenya dengan melakukan hal yang disukai oleh klien yaitu menggambar atau menonton televisi. Di akhir pekan tante mengajak klien ke tempat berenang untuk Klien juga belajar meletakkan tasnya di kamar setelah sebelumnya hanya membuang tasnya begitu tiba di rumah.

Hasil dari follow up setelah satu bulan lama pasca intervensi klien lebih semakin jarang mengamuk dan langsung memberikan respon positif ketika diajak oleh tantenya bermain di taman alun-alun kota. Anggota keluarga berusaha untuk tetap menyempatkan waktu menemani klien untuk melakukan aktivitas-aktivitas bersama klien yang dapat meluapkan emosi seperti 
Tabel 1. Hasil intervensi

\begin{tabular}{|c|c|}
\hline Sebelum Intervensi & Sesudah Intervensi \\
\hline $\begin{array}{l}\text { Klien masuk rumah dengan membuka pintu } \\
\text { rumah secara kasar, membuang tasnya dan } \\
\text { langsung menonton televisi }\end{array}$ & $\begin{array}{l}\text { Klien belajar masuk rumah dengan mengetuk } \\
\text { dan memberi salam dan meletakkan tas di } \\
\text { kamarnya }\end{array}$ \\
\hline $\begin{array}{l}\text { Klien menolak dan marah jika disuruh } \\
\text { mengganti pakaian sepulang sekolah }\end{array}$ & $\begin{array}{l}\text { Klien belajar mengganti baju sepulang sekolah } \\
\text { didampingi tantenya dan memilih bajunya } \\
\text { sendiri }\end{array}$ \\
\hline $\begin{array}{l}\text { Keluarga hanya membiarkan jika klien sedang } \\
\text { marah atau mengamuk sampai klien berhenti } \\
\text { sendiri }\end{array}$ & $\begin{array}{l}\text { Keluarga mengalihkan emosi klien dengan } \\
\text { melakukan hal yang disukai klien yaitu } \\
\text { menggambar dan menonton televisi yang } \\
\text { mana kegiatan tersebut dapat meredam } \\
\text { amarah klien. }\end{array}$ \\
\hline $\begin{array}{l}\text { Keluarga jarang mengajak klien beraktivitas } \\
\text { di luar rumah }\end{array}$ & $\begin{array}{l}\text { Keluarga membawa klien ke taman bermain } \\
\text { dan ke tempat berenang sehingga klien dapat } \\
\text { berlari-lari dan meluapkan emosinya. }\end{array}$ \\
\hline
\end{tabular}

bersepeda dan berenang. Klien terlihat lebih ceria dibandingkan sebelumnya.

\section{Pembahasan}

Keluarga memengaruhi perkembangan anak-anak mereka di banyak bidang, seperti dalam bidang keterampilan kognitif dan akademik, kemampuan berbicara dan bahasa, perilaku, dan kompetensi sosial mereka. Keluarga juga memiliki kesempatan untuk membantu dengan tantangan tambahan yang dihadapi oleh anak-anak dengan kesulitan emosi dan perilaku (Stern, 2001). Hasil penelitian pada kasus ini menunjukkan bahwa peran keluarga sangat penting untuk mengatasi problem emosi pada anak intelektual disabilitas. Dukungan dan kerjasama yang baik dari anggota keluarga dalam mendampingi klien dan mengajari klien agar berubah lebih baik sangat berpengaruh dalam kasus ini.

Dukungan keluarga membantu anggota keluarga memahami masalah yang saling terkait, berkomunikasi lebih efektif satu sama lain, dan bekerja secara kooperatif untuk menghasilkan strategi untuk membantu anak (Stern, 2001). Pada kasus ini terbukti bahwa dukungan keluarga dan kepedulian anggota keluarga dalam menciptakan strategi dan aktivitas yang dapat membantu klien dalam mengatasi problem emosi dan perilaku yang dimilikinya.

Konseling keluarga dengan pendekatan behavior yanng menjadi intervensi pada kasus ini mengajarkan anak bagaimana mengelola emosinya sehingga anak dapat belajar untuk mengendalikan emosi. Anggota keluarga diajarkan untuk memberikan perhatian kepada klien, mengalihkan perhatian klien ketika sedang marah kepada hal lain yang disukainya, dan mengajak dan mengajarkan klien kepada aktivitas positif yang dapat meluapkan emosinya. Family counseling atau konseling keluarga merupakan upaya bantuan yang diberikan kepada individu anggota keluarga melalui sistem keluarga (pembenahan komunikasi keluarga) agar potensinya berkembang seoptimal mungkin dan masalahnya dapat diatasi atas dasar kemauan membantu dari semua anggota keluarga berdasarkan kerelaan dan kecintaan terhadap keluarga (Rahayu, 2017).

\section{Kesimpulan}

Intervensi dengan konseling keluarga berpengaruh dalam mengatasi problem emosi pada anak. Anggota keluarga memahami masalah yang saling terkait, berkomunikasi lebih efektif satu sama lain, dan bekerja secara kooperatif untuk membantu problem yang terjadi pada klien. Peran 
anggota keluarga dalam intervensi ini sangat mendukung perubahan perilaku yang terjadi pada klien.

\section{Referensi}

American Psychiatric Association. (2013). Diagnostic and statistial manual (5thed.) Washington, DC: American Psychiatric Publishing.

Ar-rasily, O. K., \& Dewi, P. K. (2016). Faktor-Faktor Yang Mempengaruhi Tingkat, 5(4), 1422-1433.

Dewi, S., \& Ningtyas, Y. (2013). Hubungan Antara Self Control Dengan Internet Addiction, 1(1), 25-30.

Erlina, N., \& Fitri, L. A. (2016). Pendekatan ehavioral Untuk Mengurangi Perilaku Membolos Peserta Didik Kelas VIII MTs Miftahul Ulum Merabung III Kecamatan Pugung Kabupaten Tanggamus. Jurnal Konseli BK Tarbiyah UIN RIL, Vol 03(1), 19-28.

Hasford, R. (2015). Behavioral Counseling: A contemporary overview. University of California, 22(5), 531-556. https://doi.org/10.1177/016344300022005001

Rahayu, S. M. (2017). Konseling Keluarga Dengan Pendekatan Behavioral: Strategi Mewujudkan Keharmonisan Dalam Keluarga.Proceeding Seminar Dan Lokakarya Nasional Bimbingan Dan Konseling 2017, 1(0), 264-272.

Ramadhani, R. F., Zulfiana, U., Psikologi, F., Malang, U. M., Diri, P. K., \& Sekolah, A. U. (2019). Pelatihan Kontrol Diri Untuk Mengurangi Kecenderungan Internet Gaming DisorderPada Anak, 7(1), 81-100.

Sanyata, S. (2012). Teori dan Aplikasi Pendekatan Behavioristik dalam Konseling. Cendekia: Journal of Education and Society, (14), 1-11.

Stern, M. (2001). Children's Emotional and Learning Problems, 5(3).

Sofyan., S., W. (2007). Konseling Individual Teori dan Praktek. Bandung: Alfabeta. 